УДК 340.12

DOI https: / / doi.org/10.32837/yuv.v0i1.2080

\author{
П. Пилипишин, \\ кандидат юридичних наук, \\ докторант кафедри теорії та історії держави і права \\ Хмельницького університету управління та права імені Леоніда Юзькова
}

\title{
ФОРМУВАННЯ ІДЕЙ ІНДИВІДУАЛІЗМУ У ФІЛОСОФІї ПРАВА ДЖОНА ЛОККА
}

Постановка проблеми. Епоха Просвітництва являє собою сукупність філософсько-правових ідей, які призвели до формування індивідуалізму. Філософсько-правова думка даної доби перебувала під величезним впливом локківської інтерпретації природнього стану суспільства, в якому вчений розглядає основні права людини i, чи не вперше, відносить туди право власності, яке має як буржуазний, так і індивідуалістичний відтінок. Отже, саме Дж. Локк через свою ідеологію антропологічного індивідуалізму одиничності остаточно сформулював індивідуалізм.

Аналіз останніх досліджень i публікацій. Просвітництво як період, якому притаманні індивідуалістичні погляди, цікавило багатьох науковців, зокрема: Н.Р. Вакулич, Н.В. Дрьоміну-Вовк, Г.Г. Камардіну, О.М. Корх, М.Ю. Неврозова, Є.Н. Петрову, Ф.А. Станжевського, Є.В. Суконкіну, Є.І. Чеботарьову, В.П. Шаповалова, 3.В. Шевченка та ін. Проте їхній науковий аналіз не стосувався розкриття індивідуалістичних поглядів Дж. Локка.

Мета статті полягає у розкритті індивідуалізму через розгляд філософсько-правових поглядів Дж. Локка.

Основний матеріал дослідження. Індивідуалістичні ідеї філософії Нового часу отримують свій подальший розвиток в працях англійського філософа Дж. Локка, погляди якого на проблеми гуманістичної філософії і політичний устрій держави знаходили розуміння і віталися багатьма його сучасниками. У своїх філософських трактатах Локк дає обгрунтування політичним i правовим реформам англійського суспільства в епоху «славної» Англійської революції, спрямованої на обмеження королівської влади, на створення парламентської форми правління, на забезпечення релігійної свободи тощо. У своїй філософії Локк сприйняв і розвинув ідеї попередників - Бекона і Гоббса про людину, суспільство і державу. Як і Гоббс, Локк розглядає людей в «природному» стані як вільних, рівних і незалежних. Локк, визнаючи егоїстичні нахили людини, розробляв проблематику приватної власності і праці, як засобу їі досягнення. [1, с. 26] Дж. Локк підхопив ідею Т. Гоббса про ідею договірного походження держави. Дж. Локк та Т. Гоббс мають спільні думки 3 приводу того, що індивід виступає кінцевою соціальною реальністю, а не суспільство. Особистий інтерес, за Локком, є одним з основних мотивів людської поведінки: кожна людина бажає уникнути зла та прагне до щастя. Індивідуалізм у Локка має буржуазний характер, оскільки його вимоги повної свободи та рівності опираються на непорушності приватної власності та невтручанні держави у приватне життя та особисте процвітання людей. Філософ, інакше кажучи, декларує принцип: не людина для держави, а держава для людини. [2, с. 32] Дж. Локк 
під впливом остаточної політичної перемоги буржуазії в Англії стоїть на позиції відкритого і рішучого захисту права особи бути, а тому якщо Гоббс вважав немислимим без фактично необмеженої влади абсолютного суверена - держави, мирне становище i дотримання прав людини, то для Локка така безмежна влада несумісна зі справжніми інтересами особи. Як вважав мислитель, будь-яка влада неодмінно стає на шлях зловживань i порушень прав людини, які укорінені у природному стані суспільства, якщо керується своєю нічим не зв'язаною волею. Локк із метою захисту цих прав і висуває вимогу розподілу влади між різними іï гілками. Саме індивідуалістична відраза до авторитаризму посприяла до вимоги розподілу влади. [3, с. 81] Філософсько-правові ідеї Дж. Локка щодо обмеження втручання держави в справи громадянського суспільства та верховенства права багато в чому посприяли ідеї правового суспільства. Дж. Локк у праці «Два трактати про державне правління» обгрунтував природні права людини та дослідивши гарантії щодо їхнього додержання та захисту від сваволі влади, першим на концептуальному рівні серед мислителів в ланцюжку «особа - суспільство держава» розмістив на першому місці особу, іï потреби та інтереси, на другому - потреби й інтереси суспільства і лише на третьому - потреби й інтереси держави. [4, с. 9]

На відміну від Гоббса, який вибудував правову теорію з властивим йому культом закону і державної влади в дусі етатизму, у Локка лейтмотивом пройде ідея свободи через всю його філософсько-правову теорію. Подібна трансформація розуміння свободи не могла не викликати зміни не тільки у самій теорії договірного походження держави, а й іï базових основ, включаючи інтерпретацію природного стану суспільства. Згідно з поглядами англійського філософа Локка, у природному додержавному стані панує природний закон природи. $\mathrm{У}$ його трактуванні цей стан істотно відрізняється від гоббсівської картини війни всіх проти всіх. Будучи вираженням розумності людської природи, закон природи «вимагає миру і безпеки для всього людства». Відповідно, і людина згідно вимог розуму також і в природному стані, коли переслідує свої інтереси і відстоює своє життя, свободу і власність, прагне не нашкодити іншому. Також Локк, на відміну від Гоббса, трактує основні, тобто невід'ємні, властиві від природи права людини як право власності. Дослідник наполягає, що людина має право, причому має право саме згідно закону самої природи, відстоювати «свою власність, тобто своє життя, свободу і майно». Зводячи право власності, як бачимо, в ранг антропологічної константи, філософ постає на теоретичну позицію, властиву для природно-правової концепції [5, с. 59]. Згідно з Локком, природний стан - це «стан повної свободи стосовно дій та розпорядження своїм майном і особистістю», «стан рівності, при якому всяка влада і всяке право є взаємними, ніхто не має більше іншого» [6, с. 260]. Як вважав Локк, в основному природний стан - це стан доброзичливості і миру. Закон природи закріплює безпеку та мир. Локк стверджував, що для створення гарантій природних прав і законів люди відмовилися від права самостійно забезпечувати ці права і закони. Для гарантії природних прав (свобода, рівність, власність) i законів (мир і безпека) створена держава, яка не повинна зазіхати на ці права, повинна бути організована так, щоб природні права були надійно гарантовані [7, с. 161-167].

В основі вчення Локка лежать просвітницькі ідеї про «природне право» i «суспільний договір», що підводить до розгляду соціально-політичного процесу як розвитку людського співжиття від природного стану до цивільного самоврядування. Він при цьому розглядає приватну 


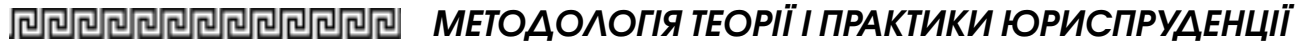

власність і працю в якості природних атрибутів людини, вважаючи, що їх первинність виступає умовою задоволення потреб [8, с. 43]. Усі наші сприйняття, згідно з Локком, супроводжуються простими ідеями задоволення чи страждання. Відсутність задоволення або ж наявність болю в даний момент, а також їх передчуття в майбутньому, створюють у нас почуття занепокоєння. Бажання пов'язано з прагненням задовольнити цей внутрішній неспокій, усунувши біль або досягнувши задоволення. При цьому задовольняється те бажання, яке викликає максимум внутрішнього неспокою. Отже, бажання $є$ занепокоєнням розуму щодо нестачі чи відсутності деякого блага. Як вважає Локк, саме занепокоєння визначає волю щодо наших дій, а не очікуване благо. Поки не вступає в гру занепокоєння, ідея всякого блага в розумі, подібно до інших ідей, є лише об’єкт пасивного умогляду, але не діє на волю і не спонукає нас до діяльності. Тут знову-таки має місце каузальний зв'язок: відсутність блага викликає занепокоєння, яке і підштовхує нас до дії. Таким чином, йдеться не про мотив до діі, що полягає в інтенціональній спрямованості на предмет, у прагненні до блага. Йдеться про чисто каузальний вплив зовнішнього світу на внутрішній механізм (механізм занепокоєння), а останнього на поведінку. Інтенціональне, смислове відношення зі світом не грає тут ніякої ролі; бажання грунтується не на змісті, а на причинності. Причинність тут має лінійний характер: від зовнішнього до внутрішнього і від внутрішнього до зовнішнього [9, с. 31].

Попри індивідуалістичні ідеї Локка, його як філософа турбують питання взаємодії людей у громаді. Незважаючи на те, що індивід $є$ власником своєї праці і це забезпечує незаперечне право на плоди праці як на індивідуальну власність, 3 іншого боку - ця ж сама праця вводить індивіда в систему відносин 3 іншими індивідами. Тому власність для Локка є основа не тільки індивідуалізації, а й соціалізації [10, с. 279-280].

Е. Соловйов зазначає: «Локк виявився великим тлумачем зароджуваної правосвідомості, він зумів зафіксувати та висловити такі іiі настанови, які не тільки зберегли свою соціальну дієвість протягом всього XVIII століття, але в певному сенсі взагалі виявилися «вічними». Парадоксальна (абсолютно незрозуміла для жодного 3 «традиційних» суспільств) ідея «рівності без зрівнювання», рівності, що допускає і більш того, що оберігає та стимулює природну несхожість людей, - одна 3 основних тем у політико-юридичних вченнях філософів, зокрема, на англійському грунті у Гоббса і Локка» [11, с. 152]. Локк вважається чи не найбільшим просвітником, який відстоював ідею рівності. Виходячи з того, що атеїзм для нього $€$ неприпустимим, він був прихильником теологічної інтерпретації основної рівності. Як вважав Локк, щоб між людьми можна було встановити принцип основної людської рівності, вони повинні мати релігійні переконання та вірити в Бога, а тому атеїсти повинні бути позбавлені громадянських прав. Можливості, які надає держава для реалізації природних відмінностей та нерівностей, на думку Локка, як це не парадоксально на перший погляд, $€$ кращим засобом для усунення неприродних привілеїв [7, с. 161-167].

За Локком, істинна рівність - це перш за все юридична рівність, тобто може йтися лише про однакові рівні права, про те, що незалежно від їхньої природної нерівності люди $€$ рівноправними суб'єктами щодо економічної, духовної та політичної сфери, також щодо власної долі. Отже, рівність, яку описує Локк, не має ніякого відношення до природної однаковості індивідів або вимоги їх штучного «зрівняння» за здібностями, силами або майном. Індивідуальні права на життя, свободу і власність є фундаментальними за своєю та нероздільні 
одне від інших, тому що кожне з них є однією гранню єдиного у своїи неподільності права кожного індивіда бути самостійним, незалежним суб'єктом своєї життєдіяльності [3, с. 81, 82].

Згідно 3 мислителем, основою всіх інших прав є свобода. Мислитель, аналізуючи міжлюдські, в тому числі і міжособистісні відносини, виділяє в ланцюзі формування щастя і свободи кілька ланок. Сприйняті від інших людей нашим розумом ідеї не залишаються в ньому в бездіяльності, оскільки вони в серці людини пускають коріння, що сприйняла їх, стають духовною, інтелектуальною підставою для здійснення дійсної, реальної свободи і відчуття щастя, повноти життя. Уявлення, зміцнюючи свій авторитет, стають уявленнями відображені в наших серцях Богом і природою, бо не бачимо іншого джерела ïх походження [2, с. 32].

Для Локка свобода - це насамперед незалежність індивіда від чужої волі, право індивіда самостійно розпоряджатися своїм майном і особистістю. Власний розум і вільна воля, даровані їй Богом, - це вищі інстанції, до яких звертається людина, які зумовлюють здатність до незалежного самовизначення. За Локком, необхідність незалежного індивідуального самовизначення обумовлена тим, що краще самого індивіда ніяка зовнішня сила не здатна усвідомити, в чому полягає iii власне благо і визначити шляхи, що ведуть до нього. Це пояснюється тим, що ця проблема більше самого індивіда не хвилює нікого, у тому числі і державу. Природа людського розуму до того ж така, що навіть під тортурами ніяка зовнішня сила не здатна примусити його змінити судження, яке розум склав про речі [3, с. 81]. У філософсько-правових роздумах Джона Локка людина мислиться як вільна, рівна і незалежна. «Свобода людини в суспільстві полягає в тому, що він не підкоряється ніякій іншій законодавчій владі крім тієї, яка встановлена за згодою в державі, і не зна- ходиться в підпорядкуванні будь-чиєї волі ...». [10, с. 274]

Дж. Локк вважав, що свобода притаманна людям, невіддільна від них. Одна із природних якостей людини захищати свої природні можливості: рівність, свободу, власність від зазіхань на них. Вчений проголошує можливість існування для людини абсолютної свободи, справедливої i істинної, рівної і безпристрасної. Локк у суспільних відносинах бачив прояв свободи людей в тому, щоб жити, дотримуючись загальноприйнятих законів, вільно слідувати своїм бажанням, якщо вони не суперечать законам. Свобода індівіда в соціумі, згідно з філософом, - це обмежена, неабсолютна свобода, проте вона має широкий діапазон: індивід може в рамках закону як йому завгодно розпоряджатися своїми правами, це свобода від будь-яких проявів свавілля. Звідси Локк робить висновок, що свобода і розум так само тісно зв'язані між собою, як і несвобода і нерозумність [12, с. 30]. Джон Локк також, як i його сучасники, бачив підставу свободи людини в тому, «що вона має розум, який в змозі навчити iii тому закону, за яким вона повинна собою керувати, і дати їй зрозуміти, якою мірою у неї залишається свобода ї̈ власної волі» [13, с. 297].

Джон Локк зрівнює свободу із самоприналежністю. Людське «я» (self) чинить опір спробам позбавити його власності - саме в цей контекст вписується ідея «прав людини», розроблена Локком. Однак найсильнішу дію Джона Локка на розвиток індивідуалізму пов'язують скоріше з його епістемологією і 3 філософією свідомості. Тут потрібно виділити три аспекти індивідуалістичної філософії Локка. По-перше, теорія ідей Локка, яку слід інтерпретувати як ранню форму репрезентаціонізма, згідно 3 яким суб'єкт має безпосередній контакт не зі світом, але 3 опосередкованими репрезентаціями світу. По-друге, уявлення про сприйняття 


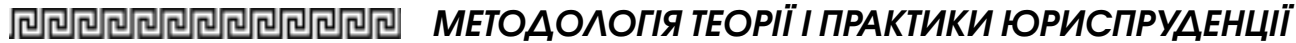

як про продукт лінійної каузальності від зовнішнього до внутрішнього. По-третє, прояснення мотивації і дії через внутрішні механізми занепокоєння: це уявлення розриває інтенціональний зв'язок суб'єкта зі світом, зводячи дію і мотивацію до внутрішніх каузальних механізмів індивіда. Всі ці три аспекти інтерналізму або індивідуалізму донині впливають на розуміння свідомості в когнітивних науках і частково у філософії свідомості. Всі ці тези Локка свою актуальність зберігають у сучасній індивідуалістичній філософії [9, с. 5].

Дж. Локк, продовжуючи ідею договірного походження держави, на відмінну від Т. Гоббса, більше акцентував на індивідуалістичних тенденціях, аніж суспільних, вважаючи, що індивід повинен мати політичну, духовну та економічну самостійність i бути вільним суб'єктом вибору та дії. Зосереджуючись на індивідуалістичному аспекті спадщини англійського філософа, слід звернути увагу на його основні філософсько-правові постулати:

1) індивідуальні права на життя, свободу і власність $є$ фундаментальними за своєю суттю та нероздільними одне від інших;

2) свобода $€$ основою всіх інших прав; ця свобода передбачає свободу від різних відносин з іншими, крім тих, в які індивід вступає добровільно з урахуванням власного інтересу;

3) свобода від залежності щодо інших робить нас людьми;

4) свобода кожного індивіда може бути обмежена тільки такими правилами і обов'язками, які необхідні для того, щоб забезпечити таку ж свободу іншим;

5) рівність не зрівнює, а оберігає і стимулює природну несхожість людей;

6) люди $є$ рівноправними суб'єктами щодо економічної, духовної та політичної сфери і власної долі;

7) людина має право задовольнити свободу тим способом, якими йому до вподоби, а не порушувати законів справедливості;

8) по суті, індивід є власником своєї особистості і здібностей, і в цьому відношенні він нічим не зобов'язаний суспільству;

9) лише сам індивід може визначити в чому полягає його власне благо;

10) право власності є антропологічною константою, а праця - це первинна умова задоволення потреб;

11) людське суспільство грунтується на ринкових відносинах;

12) держава $€$ результатом суспільної домовленості для захисту власності індивіда в його особі і у вигляді благ, і отже, збереження впорядкованих відносин обміну між індивідами, які розглядаються як власники самих себе;

13) невтручання держави у приватне життя та особисте процвітання людей.

У статmi робиться спроба розкриття індивідуалізму у філософіï права Джона Локка. Філософсько-правова думка доби Просвітництва перебувала піә величезним впливом локківської інтерпретації природнього стану суспільства, в якому вчений розглядає основні права людини $i$, чи не вперше, відносить туди право власності, яке має як буржуазний, так $і$ індивідуалістичний відтінок. Дж. Локк, продовжуючи ідею договірного походження держави, на відмінну від T. Гоббса, більше акцентував на індивідуалістичних тенденціях, аніж суспільних, вважаючи, що індивід повинен мати політичну, духовну та економічну самостійність $i$ бути вільним суб'єктом вибору та діi.

Зосереджуючись на індивідуалістичному аспекті спадщини англійського філософа, звернено увагу на його основні філософсько-правові постулати: індивідуальні права на життя, свободу $i$ власність 
є фундаментальними за своєю суттю та нероздільними одне від інших; свобода є основою всіх інших прав; ия свобода передбачає свободу від різних відносин з іншими, крім тих, в які індивід вступає добровільно з урахуванням власного інтересу; свобода від залежності щодо інших робить нас людьми; свобода кожного індивіда може бути обмежена тільки такими правилами $i$ обов'язками, які необхідні для того, щзоб забезпечити таку ж свободу іншим; рівність не зрівнюе, а оберігає і стимулюе природну несхожість людей; люди є рівноправними суб’єктами щзоо економічної, духовної та політичної сфери і власної долі; людина має право задовольнити свободу тим способом, якими йому до вподоби, а не порушувати законів справедливості; по суті, індивід є власником своєї особистості $i$ здібностей, $і$ в иьому відношенні він нічим не зобов'язаний суспільству; лище сам індивід може визначити, в чому полягає його власне благо; право власності є антропологічною константою, а праця - ие первинна умова задоволення потреб; людське суспільство складається з ринкових відносин; держава є результатом суспільної домовленості для захиcmy власності індивіда в його особі i у вигляді благ, $i$ отже, збереження впорядкованих відносин обміну між індивідами, які розглядаються як власники самих себе; невтручання держави у приватне життя та особисте процвітання людей.

Ключові слова: індивідуалізм, індивід, Просвітництво, раціоналізм, рівність, держава, свобода, власність.

Pylypyshyn P. Formation of ideas of individualism in the philosophy of law of John Locke

The article reveals formation peculiarities of ideas of individualism in the John Locke's philosophy of law. It was proved that the philosophical and legal thought of the Enlightenment had been greatly influenced by Locke's interpretation of the natural state of society, in which the scientist sees essential human rights and maybe for the first time refers to it the right of ownership, which has both bourgeois and individualist overtones. J. Locke, following the idea of the contracting origin of the state, opposed to T. Hobbes, emphasized individualist tendencies more than social ones; considering that an individual should have political, spiritual and economic independence and be a free subject of choice and action.

Focusing on individualist aspect of the English philosopher's heritage, the attention is paid to his main philosophical and legal postulates: individual rights to life, freedom and ownership are fundamental by nature and indivisible from each other; liberty is the basis of all other rights; this liberty implies freedom from different relations with others, except of those in which the individual enters freely considering interest of his own; freedom from dependence against others makes us human; the freedom of each individual may be limited only by such rules and obligations which are necessary to provide the same freedom for others; equality does not equalize, but protects and stimulates the natural human differences; people are equal subjects in relation to economic, spiritual and political spheres and to their own destiny; a person has the right to satisfy freedom in the way he likes, and not to violate the laws of rights; in fact, the individual is the owner of his personality and abilities, and he owes nothing to society in this respect; only the individual himself can determine his own benefit; the right of ownership is an anthropological constant, and labor is the primary condition for meeting the needs; human society consists of market relations; the state is the result of a social arrangement to protect 


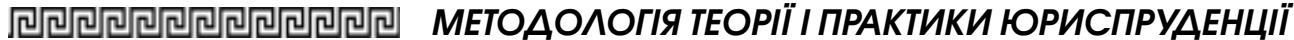

ownership of an individual through him and in the form of benefits, and hence keeping structured relations of exchange between individuals who are regarded as owners of themselves; noninvolvement of the state into private life and personal well-being of people.

Key words: individualism, individual, the Enlightenment, rationalism, equality, state, freedom, ownership.

\section{Література}

1. Невзоров М.Ю. Гуманистическая направленность правовой культурь (Соииально-философский аспект) дис. ... канд. филос. наук : 09.00.11: Липеик, 2004. 155 c.

2. Шевченко 3.В. Індувідуалізм як складова розвитку демократії : дис. ... канд. юрид. наук : 09.00.03. Київ, 2005. $228 \mathrm{c}$.

3. Корх О.М. Проблема індивідуалізму (історико-філософський аналіз) : дис. ... д-ра філос. наук : 09.00.05; Дніпропетровський національний ун-т. Дніпро, 2002. 397 c.

4. Ковальова Г.П. Ідея правового суспільства: виникнення та розвиток. Вісник Харківського національного педагогічного університету імені Г.С. Сковороди. Філософія. 2013. Bun. 40(2). C. 6-18.

5. Чеботарева Е.И. Онтология права и гражданского общества: философский анализ : философский анализ : дис. ... канд. филос. наук : 09.00.11. Саратов, 2007. $160 \mathrm{c}$.

6. Нстория политических и правовых учений : учебник / под ред. О.Э. Лейста. Москва: Зериало, 2000. 688 с.

7. Дрьоміна-Волок Н.В. Розвиток ідеалів рівності та апологетика расового рабства в пращях Дж. Локка і Т. Гоббса. Наукові праці Національного університету «Одеська юридична академія». 2012. T. 11. C. 160-169.

8. Камардина Г.Г. Свобода как родовая характеристика общественного бытия : дис. ... канд. филос. наук : 09.00.11: Ульяновск, 2004. 126 с

9. Станжевский Ф.А. Индивидуализм в философии сознания и неиндивидуалистические конщепци ментального состояния : диссертащия ... кандидата философских наук: 09.00.13, 2017. 176 c.

10. Локк Дж. Сочинения: В $3 \mathrm{~m}$. / пер. с англ. и лат. Т. 3 / Ред. и сост., авт. примеч. А.Л. Субботин. Москва : Мысль, 1988. $668 \mathrm{c}$

11. Соловьев Э.Ю. Прошлое толкует нас (Очерки по истории философии и культуры). Москва : Политиздат, 1991. $432 \mathrm{c}$

12. Вакулич Н.Р. Свобода и личность: Соииокультурнье основания : дисс. .. канд. филос. наук: 09.00.11. Саратов, 2001. $131 \mathrm{c}$.

13. Лейбнии Г.В. Переписка с П. Бейлем. Лейбнии Г.В. Сочинения: в 4 т. Т. 3. Москва, 1984. С. 345-371. 